\title{
Anatomical Structures and Fiber Quality of Four Lesser-Used Wood Species Grown in Indonesia ${ }^{1}$
}

\author{
Sari Delviana MARBUN ${ }^{2} \cdot$ Imam WAHYUDI $^{3, \dagger}$ • \\ Jajang SURYANA ${ }^{3} \cdot$ Deded Sarip NAWAWI ${ }^{3}$
}

\begin{abstract}
This study aimed to investigate the anatomical structure and fiber quality of four lesser-used wood species namely Benuang (O. sumatrana), Duabanga (D. moluccana), Pisang Merah (H. hellwigii), and Terap (A. odoratissimus). This study evaluated its suitability for raw material in pulp and paper manufacturing. The anatomical structure was observed macro- and microscopically. Macroscopic structures were observed directly to the wood samples, while microscopic characteristics were observed through microtome specimens. Fiber dimension was measured through macerated specimens and fiber quality was analyzed following the Rachman and Siagian's method. Results showed that these four timber species have similarity in the indistinct growth ring, diffuse porous in a radial pattern, rounded solitary vessel outline, 1 to 3 cells of ray width, deposits within the rays, fiber length, and cell wall thickness. Differences were found on vessel diameter, vessel grouping, vessel frequency, tyloses existence, type of axial parenchyma, and ray height. Based on fiber length and its derived values, the wood fibers of all species studied are suitable for pulp and paper manufacturing. They belong to the II quality class. The produced pulp and paper would have good quality, especially in tensile, folding, and tear strength. To promote their utilization, silviculture aspect of these four species has to be well understood.
\end{abstract}

Keywords: anatomical structure, Artocarpus odoratissimus, Duabanga moluccana, fiber quality, Horsfieldia hellwigii, Octomeles sumatrana

\section{INTRODUCTION}

In Indonesia, the forestry sector has an essential role in many aspects. The Indonesian forestry sector had relied on wood industries especially plywood, sawn timber, and others from 1970 to 1990 . At that time, Indonesia was well known as the biggest plywood producer and exporter. However, since the last two decades, wood industries were replaced by pulp and paper industries. According to Statistics Indonesia (BPS 2014a; 2014b; 2015; 2016; 2017), the Indonesian export volume of pulp and paper increased significantly from 4.8 to 6.0 million ton during the last five years, while the productivity of timber industries decreased.

Pulp and paper industries in Indonesia highly depend on wood from plantation forests in the last twenty years.

\footnotetext{
1 Date Received March 19, 2019, Date Accepted August 23, 2019

${ }^{2}$ Science and Forest Products Technology Study Program, Bogor Agricultural University (IPB University), Bogor, 16680, Indonesia

${ }^{3}$ Department of Forest Products, Faculty of Forestry, Bogor Agricultural University (IPB University), Bogor, 16680, Indonesia

$\dagger$ Corresponding author: Imam WAHYUDI (e-mail: imyudarw16@yahoo.com, ORCID: 0000-0001-9062-9264)
} 
The forest was established either by local people or corporation using fast-grown tree species, especially Mangium (Acacia mangium), Sengon (Falcataria moluccana), and Eucalyptus (Eucalyptus spp.). Though pulpwood from plantation forests increases every year, some species from the natural rainforest are still needed to improve the characteristic of pulp and paper produced. However, the suitability of the species has not been proven scientifically. Wood characteristics, especially in anatomical structure and fiber quality, have to be properly investigated to improve the quality of pulp and paper (Hidayat et al., 2017).

According to Soerianegara et al. (1993) and Mandang (2013), there are approximately 4000 potential wood species in Indonesian tropical rainforest, and only less than $10 \%$ has been utilized. There is a lot of wood species that can be selected and used for the candidate. Benuang (Octomeles sumatrana), Duabanga (Duabanga moluccana), Pisang Merah (Horsfieldia hellwigii), and Terap (Artocarpus odoratissimus) which are categorized as lesser-used wood species are a prospective source because of its abundance in natural forests. Understanding of these species' characteristics will lead to the evaluation of its potential in wood markets. Some researchers have done a similar project. They characterized some lesser-known and lesser-used wood species to promote the utilization (Poku et al., 2001; Olson, 2003; Ishengoma et al., 2004; Shupe et al., 2005; Grünewald et al., 2009; Junior et al., 2009; Ali, 2011; Ogunwusi, 2012). These characteristics, which are varied among species as well as within and among the trees, can be used to predict an appropriate processing and proper utilization of the wood (Barnett and Jeronimidis, 2003; Wahyudi, 2013; Hidayati et al., 2017; Park et al., 2017; Yang et al., 2017; Park et al., 2018; Purusatama et al., 2018). Hence, it is important to characterize the properties of lesser-used wood species to predict the appropriate processing technique and proper utilization.
This study aimed to characterize the four lesser-used wood species, especially their anatomical structures and fiber quality to evaluate its suitability in pulp and paper manufacturing. An evaluation was conducted by comparing the characteristics of experimental species with general raw materials in pulp and paper manufacturing (Mangium, Sengon, and Eucalyptus).

\section{MATERIALS and METHODS}

\subsection{Brief description of the experimental wood species}

\subsubsection{Benuang (O. sumatrana, Datiscaceae)}

The trees are large to very large, dioecious evergreen, 45-60 m tall, and about 90-250 cm in diameter. The trunk is straight, cylindrical, branchless up to $30 \mathrm{~m}$, and buttressed 3-6 m high. The outer bark is thick up to $5 \mathrm{~mm}$, greyish brown color, and has shallow streaks. The natural distribution of this species ranges from the Philippine, Sumatera, Kalimantan, Sulawesi, Moluccas, and New Guinea. In Indonesia, it grows on low altitude riverside land up to $1000 \mathrm{~m}$ asl. (Martawijaya et al., 2005; ITTO’s site; Ogata et al., 2008). According to Martawijaya et al. (2005), Ogata et al. (2008), and Susila (2010), Benuang belongs to the fast-growing and pioneer species.

\subsubsection{Duabanga (D. moluccana, Sonneratiaceae)}

The genus of Duabanga consists of two species, $D$. molucanna in Kalimantan, Java, Timor, the Philippine, Sulawesi, the Moluccas, and New Guinea; and D. grandiflora from the Himalayas to Southern China, Andaman Islands, and Malaya. The trees are medium to fairly large, $35-45 \mathrm{~m}$ tall, and up to $100 \mathrm{~cm}$ in diameter. The trunk is straight, cylindrical, without buttress (ITTO's site; Ogata et al., 2008). According to ITTO's site, the trees growing in the forest along 
streams at a low altitude up to $1200 \mathrm{~m}$ asl. and frequently present in regrowth and riverside areas.

\subsubsection{Pisang Merah (H. hel/wigii, Myristicaceae)}

According to Krisdianto et al. (2013), and ITTO's site, the trees are small to medium-large, $30 \mathrm{~m}$ tall, and about $60 \mathrm{~cm}$ in diameter. The trunk is straight, cylindrical, and occasionally has small buttress. The bark is smooth and greyish white. The natural distribution of this species is from the Malay Peninsula, Kalimantan, Sumatera, and Java to New Guinea. According to Ogata et al. (2008), the trees growing scattered in lowlands, lower montane, or rarely montane rain forests up to $1200 \mathrm{~m}$ asl.

\subsubsection{Terap ( $A$. odoratissimus, Moraceae)}

The trees are medium to large and 35-43 m tall. The trunk is straight, cylindrical, without buttress, and often about $65 \mathrm{~cm}$ in diameter. The bark is brown to greyish brown and dense woolly. The natural distribution of this species ranges from India to Southeast Asia and Western Pacific. In Indonesia the tree growing on lowland evergreen forest to $750 \mathrm{~m}$ asl. (Abdurrohim et al., 2004; ITTO’s site; Ogata et al., 2008).

\subsection{Sample preparation}

The main materials were $5 \mathrm{~cm}$ thick wood discs of Benuang, Duabanga, Pisang Merah, and Terap from tropical rainforest in Kalimantan, Indonesia. Infor-

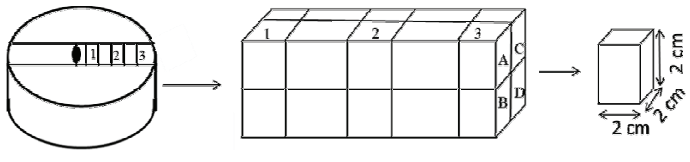

$$
\begin{aligned}
& \text { A }=\text { Macroscopic sample } \\
& \text { B }=\text { Microscopic sample } \\
& \text { C }=\text { Specific gravity } \\
& \text { D }=\text { Fiber quality }
\end{aligned}
$$

Fig. 1. Schematic of sample preparation.

mation on the experimental materials is presented in Table 1.

A small block of $2 \mathrm{~cm}$ (width) by $5 \mathrm{~cm}$ (thick) by $5 \mathrm{~cm}$ (length) was prepared from wood disc representing three locations, i.e. near the pith ( $1^{\text {st }}$ segment), middle ( $2^{\text {nd }}$ segment), and near the bark ( $3^{\text {rd }}$ segment). Wood blocks were then divided again into four parts of $2 \mathrm{~cm}$ by $2 \mathrm{~cm}$ by $2 \mathrm{~cm}$ for each parameter studied (Fig. 1).

\subsection{Macro- and microscopic observations}

Macroscopic characteristics, namely wood color, odor, texture, grain, luster, and heartwood percentage, were directly observed using loupe of 15 times magnification. Microscopic characteristics observation was carried out through the thin microtome specimens by light microscope (Zeiss Axio Imager. A1m). The

\begin{tabular}{|c|c|c|c|c|c|c|}
\hline \multirow[b]{2}{*}{ Species } & \multirow[b]{2}{*}{$\begin{array}{l}\text { Diameter } \\
(\mathrm{cm})\end{array}$} & \multirow[b]{2}{*}{$\begin{array}{l}\text { MC } \\
(\%)\end{array}$} & \multirow[b]{2}{*}{ SG } & \multicolumn{3}{|c|}{ Distance from the Pith $(\mathrm{cm})$} \\
\hline & & & & $\begin{array}{l}\text { Near the Pith } \\
\left(1^{\text {st }} \text { Segment) }\right.\end{array}$ & $\begin{array}{c}\text { Middle } \\
\text { (2 } 2^{\text {nd }} \text { Segment) }\end{array}$ & $\begin{array}{l}\text { Near the Bark } \\
\left(3^{\text {rd }} \text { Segment) }\right.\end{array}$ \\
\hline O. sumatrana & $50-70$ & 23.07 & 0.33 & 3 & 11 & 20 \\
\hline D. moluccana & $50-60$ & 35.65 & 0.35 & 3 & 11 & 20 \\
\hline H. hellwigii & $50-60$ & 22.09 & 0.45 & 3 & 11 & 20 \\
\hline A. odoratissimus & $50-70$ & 32.34 & 0.41 & 3 & $7^{*}$ & 20 \\
\hline
\end{tabular}
specimen of $25 \mu \mathrm{m}$ was produced by sliding microtome using safranin as a dying agent. The IAWA Hardwood

Table 1. Information on the experimental materials

\footnotetext{
* Transition zone from sapwood to heartwood
} 
List of IAWA Committee (Wheeler et al., 1989) was used as a reference for anatomical characteristics observation.

\subsection{Fiber dimension and its derived value measurement}

Fiber dimensions, namely fiber length, fiber diameter, and lumen diameter, were measured through macerated specimens using the same light microscope equipped with a camera. Cell wall thickness was half of the difference between fiber diameter and lumen diameter. Maceration process was based on the modification of Franklin's method (Rulliaty, 1994). A total of 50 individual fibers were measured for each segment. The derived values of fiber dimension namely Runkel ratio (RR), felting power (FP), Muhlsteph ratio (MR), flexibility ratio (FR), and coefficient of rigidity (CR) were calculated following the equations:

$$
\begin{aligned}
\mathrm{RR} & =\frac{2 \mathrm{w}}{\mathrm{l}} \quad \ldots \ldots . . . \\
\mathrm{FP} & =\frac{\mathrm{L}}{\mathrm{d}} \quad \ldots . . . \\
\mathrm{FR} & =\frac{\mathrm{l}}{\mathrm{d}} \\
\mathrm{CR} & =\frac{\mathrm{w}}{\mathrm{d}}
\end{aligned}
$$

$$
\begin{aligned}
& \text { Where, } \\
& \begin{array}{l}
\mathrm{w}=\text { fiber wall thickness } \\
\mathrm{L}=\text { fiber length } \\
\mathrm{l}=\text { diameter lumen } \\
\mathrm{d}=\text { diameter fiber }
\end{array}
\end{aligned}
$$

The derived values were then used to determine fiber quality class following Rachman and Siagian (1976), as described in Table 2.

\section{RESULTS and DISCUSSION}

\subsection{Anatomical structure}

\subsubsection{Benuang (O. sumatrana)}

Results showed that heartwood is yellowish-brown but quite easy to be differentiated from sapwood (Fig. 2A). Wood texture is medium and even, wood grain is straight to interlocked (Fig. 2A\&B) while growth ring indistinct (Fig. 2C). The wood surface is dull and has no specific odor. From the measurement, it was found that the heartwood portion is $63.38 \%$.

Results also showed, that wood is diffuse-porous and there is no distinct difference in pore size between earlywood and the latewood (Fig. 3A). Most vessels are solitary and in radial arrangement, partly multiple 2 cells (Fig 3A: arrows). Average lumen diameter is $182.29(141.90-231.89) \mu \mathrm{m}$ and vessel frequency is 5 (4-6) cells per $\mathrm{mm}^{2}$. The solitary vessel is rounded

Table 2. Criteria of fiber quality for pulp and paper manufacturing

\begin{tabular}{lcccccc}
\hline \multirow{2}{*}{ Criteria } & \multicolumn{2}{c}{ Class I } & \multicolumn{2}{c}{ Class II } & \multicolumn{2}{c}{ Class III } \\
\cline { 2 - 6 } & Requirement & Value & Requirement & Value & Requirement & Value \\
\hline \hline Fiber length $(\mu \mathrm{m})$ & $>2000$ & 100 & $1000-2000$ & 50 & $<1000$ & 25 \\
Runkle ratio $(\mathrm{RR})$ & $<0.25$ & 100 & $0.25-0.50$ & 50 & $>0.50$ & 25 \\
Felting power (FP) & $>90$ & 100 & $50-90$ & 50 & $<50$ & 25 \\
Muhlsteph ratio (MR) & $<30$ & 100 & $30-60$ & 50 & $>60$ & 25 \\
Flexibility ratio (FR) & $>0.80$ & 100 & $0.50-0.80$ & 50 & $<0.50$ & 25 \\
Coef. of rigidity (CR) & $<0.10$ & 100 & $0.10-0.15$ & 50 & $>0.15$ & 25 \\
\hline SCORING & $450-600$ & & $225-449$ & & $<225$ & \\
\hline
\end{tabular}


Anatomical Structures and Fiber Quality of Four Lesser-Used Wood Species Grown in Indonesia
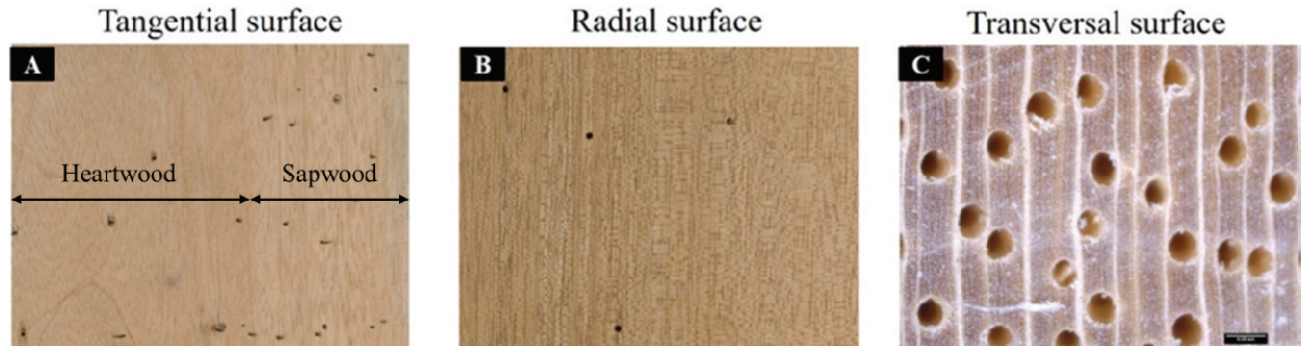

Fig. 2. Macroscopic features of Benuang (O. sumatrana).
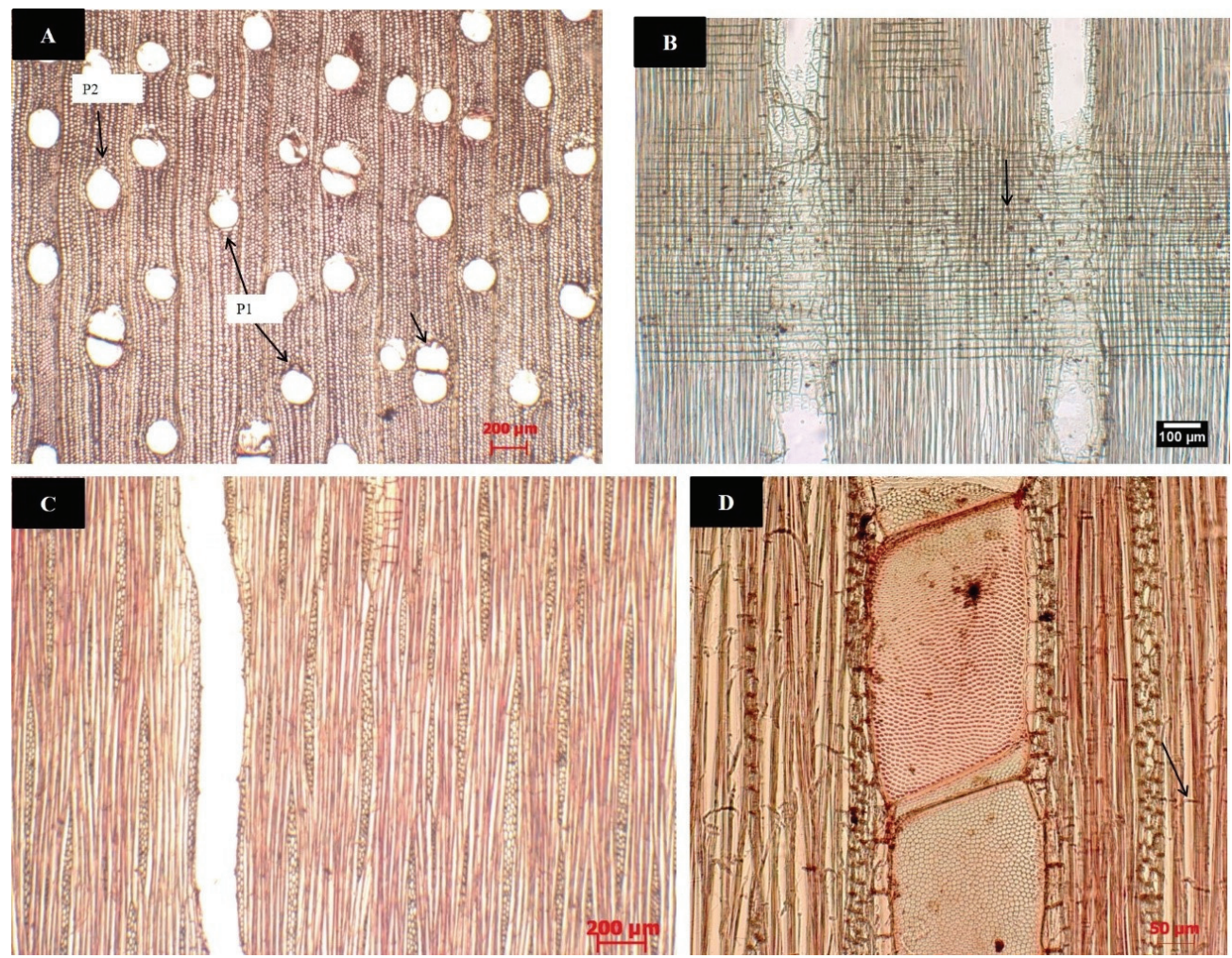

$\mathrm{P} 1$ = scanty parenchyma

$\mathrm{P} 2$ = sheath narrow parenchyma

Fig. 3. Microscopic features of Benuang (O. sumatrana).

in transversal section. Perforation plate is simple, while inter-vessel pitting is alternate with a polygonal shape (Fig. 3D). Gum, tyloses, and other deposits are not present.
Fibers are septate and non-septate (Fig. 3D: arrows), the average length of 1565.61 (844.75-2561.5) $\mu \mathrm{m}$, very thin-walled $(2.93 \mu \mathrm{m})$, with simple to minutely bordered pits. 
Axial parenchyma is rare, narrow to slightly wide and short; 1-4 cells width; and have >8 cells per strand. (Fig. 3A\&B). Apotracheal axial parenchyma is diffuse, while paratracheal axial parenchyma is scanty (Fig. 3A: $\mathrm{P} 1$ ), and the sheath is narrow (Fig. 3A: P2).

Rays' width is 1 to 3 cells (Fig. 3C), average height is 738.10 (309.91-1414.47) $\mu \mathrm{m}$, and have 5 (4-6) cells per mm. The Body ray consists of procumbent cells with 2-4 rows of the square marginal cells (Fig. 3B).

These findings, especially the vessel diameter and vessel frequency, are following Ogata et al. (2008), but not for fiber length, cell wall thickness, type of parenchyma, type of fiber, the existence of crystal and silica. The fiber in our study is shorter, thicker, and septated; the axial parenchyma is scanty and sheath narrow (theirs are vasicentric and aliform). Furthermore, silica was observed in our study, but not the crystal.

Compared to Martawijaya et al. (2005), the similarity is found in vessel distribution, vessel diameter, vessel frequency, fiber length, cell wall thickness, type of parenchyma, and ray width, while un-similarity is found in tyloses, ray height, and ray frequency. Tyloses were absent in our study, but the ray cell is taller and has a higher frequency.

\subsubsection{Duabanga (D. moluccana)}

The results showed that heartwood is pale yellowish-brown and challenging to differentiate from sapwood (Fig. 4A). Wood texture is moderate to coarse, wood grain is interlocked (Fig. 4A\&B), while growth ring boundaries are indistinct (Fig. 4C). The wood surface is dull and have no specific odor.

The result showed that wood is diffuse-porous, and there is no clear distinction in pore size between earlywood to latewood (Fig. 5A). Most of the vessels are solitary, but sometimes the radial multiple 2 cells and clustering up to 3 cells (Fig. 5A: CL). The average diameter of the lumen was 279.51 (196.55-383.51) $\mu \mathrm{m}$ and $3(2-4)$ cells per $\mathrm{mm}^{2}$. The solitary vessel is rounded in transversal section. Perforation plate is simple, while inter-vessel pitting is alternate with a polygonal shape (Fig. 5C: arrows). Gum, tyloses, and other deposits are not present.

Fibers are septate and non-septate (Fig. 5D: arrows), the average length of 1599.39 (763.00-2670.50) $\mu \mathrm{m}$, very thin-walled $(3.47 \mu \mathrm{m})$ with simple to minutely bordered pits.

Axial parenchyma is wide and long (Fig. 5B\&F) and mostly more than three cells in width and eight cells per strand. The apotracheal axial parenchyma is diffuse, while paratracheal axial parenchyma is vasicentric either sheath broad (Fig. 5A: SB), sheath narrow (Fig. 5A: $\mathrm{SN}$ ), complete circular to oval sheath (Fig. 5B: PK) or incomplete (Fig. 5B: PA), as well as confluent (Fig. 5B: PK).

Rays exclusively uniseriate (Fig. 5D), the average length of 210.81 (79.03-336.29) $\mu \mathrm{m}$, and 5 (4-6) cells per mm. Rays composition varies, square cells with 1-2 rows of upright marginal cells (Fig. 5E: J1); procumbent cells with $1-2$ rows of upright marginal
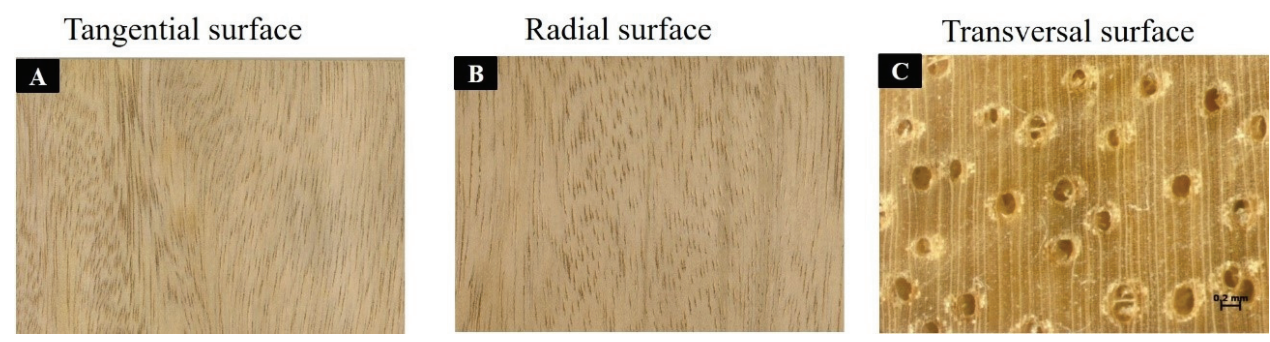

Fig. 4. Macroscopic features of Duabanga (D. moluccana). 
Anatomical Structures and Fiber Quality of Four Lesser-Used Wood Species Grown in Indonesia
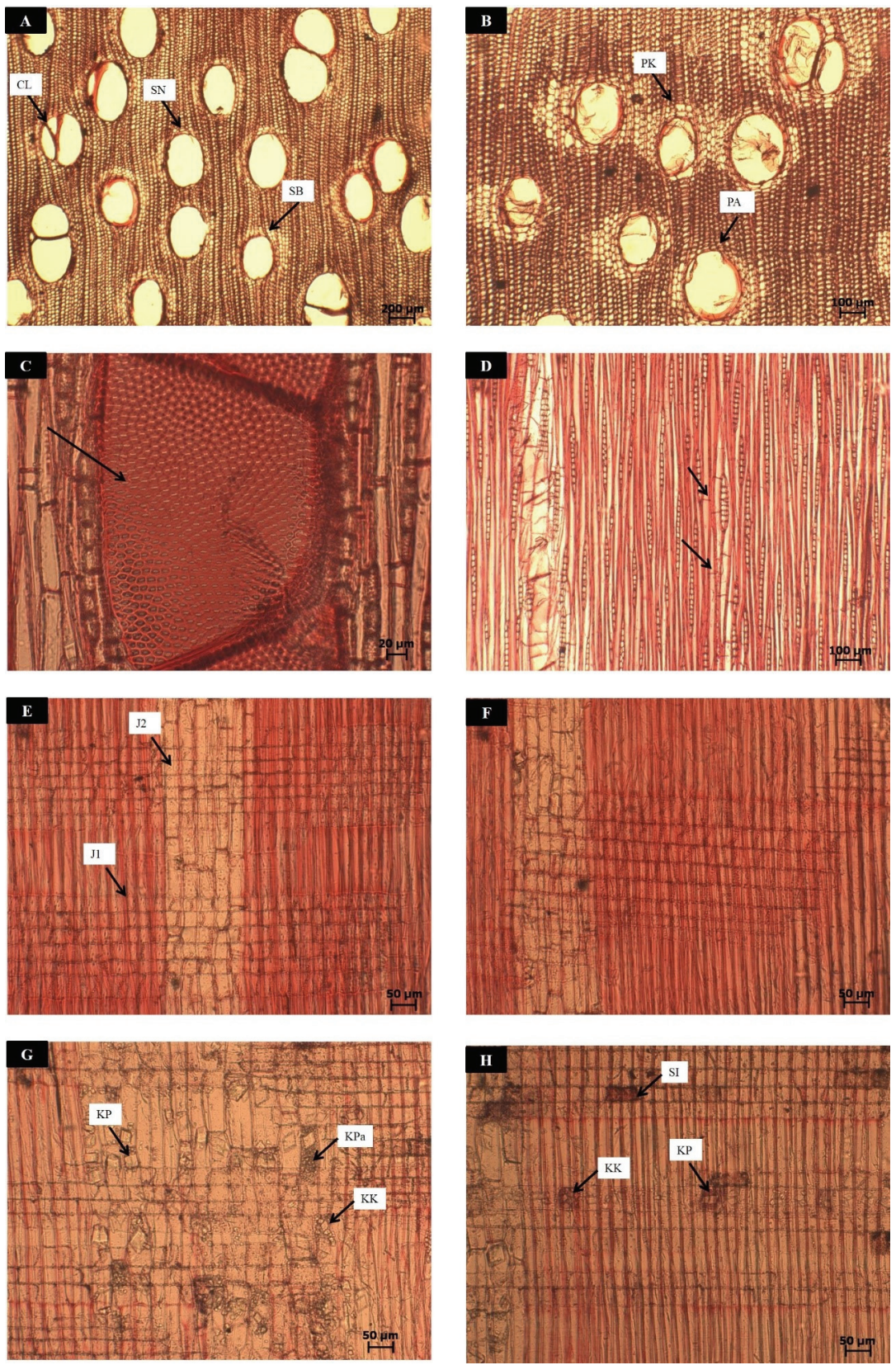

$\mathrm{CL}=$ clustered vessels

$\mathrm{J} 1$ = square cells with $1-2$ rows upright cells

$\mathrm{J} 2$ = procumbent cells with $1-2$ rows upright cells

$\mathrm{KK}=$ cubic crystals

$\mathrm{KP}=$ prismatic crystals

Kpa $=$ crystal sand
$\mathrm{PA}=$ incomplete vasicentric parenchyma

$\mathrm{PK}=$ complete circular to oval sheath vasicentric parenchyma $\mathrm{SB}=$ sheath broad parenchyma

$\mathrm{SI}=$ silica

$\mathrm{SN}=$ sheath narrow parenchyma.

Fig. 5. Microscopic features of Duabanga (D. moluccana). 
cells (Fig. 5E: J2); and procumbent, square, and upright cells mixed throughout the ray (Fig. 5F).

Furthermore, Duabanga wood, especially xylem area near to the bark, has loads of crystals in ray and axial parenchyma. In one chamber, there is one or more crystal. Prismatic crystals (Fig. 5G: KP), small cubic crystals (Fig. 5G: KK), and crystal sand (Fig. 5G: KPa) are found in axial parenchyma; while prismatic crystals (Fig. 5H: KP) and small cubic crystals (Fig. 5H: KK) are found in ray parenchyma. Silica was also found in ray parenchyma (Fig. 5H: SI).

These findings especially vessel distribution, vessel frequency, vessel diameter, ray wide, fiber length, type of axial parenchyma, and the existence of crystal are in accordance with Ogata et al. (2008), but not for the cell wall thickness, ray height, type of fiber, and existence of tyloses and silica. When compare to Ogata et al. (2008), the cell wall of Duabanga wood is thicker, but the ray is shorter. Furthermore, septate fiber and silica exist, but tyloses absent.

\subsubsection{Pisang Merah ( $H$. hellwigii)}

The results showed that heartwood is reddish-brown but slightly challenging to distinguish from the sapwood (Fig. 6A). The wood texture is medium and even, wood grain is straight (Fig. 6B), while growth ring boundaries slightly distinct to indistinct (Fig. 6C). The wood surface is slightly luster and without specific odor.

Results showed that wood is diffuse-porous and there is no significant difference in pore size between earlywood to the latewood (Fig. 7A). Most vessels are radial multiples of $2-4$ cells, partly solitary and clustering up to 3 cells (Fig. 7A: CL). The average lumen diameter is $152.80(72-219.60) \mu \mathrm{m}$, and 5 (4-7) cells per $\mathrm{mm}^{2}$. The solitary vessel is round in the transverse section. Perforation plate is simple, while inter-vessel pitting is alternate with a polygonal shape (Fig. 7C: arrows). Gum, tyloses, and other deposits are not present.

Fibers are non-septate, the average length of 1691.86 (1062.75-2507) $\mu \mathrm{m}$, very thin-walled (3.46 $\mu \mathrm{m})$ with simple to minutely bordered pits.

Axial parenchyma is narrow to slightly wide and long (Fig. 7A\&E), consisted of 2-5 cells width and more than eight cells per strand. Apotracheal axial parenchyma is diffuse-in-aggregates, which is grouped into short discontinuous tangential line (Fig. 7A: DA). Paratracheal axial parenchyma is scanty (Fig. 7B: P1) and sheath narrow (Fig. 7A: P2). Banded marginal parenchyma (Fig. 7A: DA) was also detected both in narrow (1-3 cells) (Fig. 7A: BP1) and wide bands (>3 cells) (Fig. 7A: BP2).

Rays wide is 1 to 3 cells (Fig. 7D), the average height of 449.89 (140.63-862.12) $\mu \mathrm{m}$, and have 9 (6-12) cells per mm. Body ray consists of procumbent cells with 1 to 2 rows of square marginal cells (Fig. 7E\&F). The diffuse silica bodies present in ray cells (Fig. 7B\&F), while oil and/or mucilage cells associated with ray parenchyma (Fig. 7C, SM).

Compared to Ogata et al. (2008), the similarity was
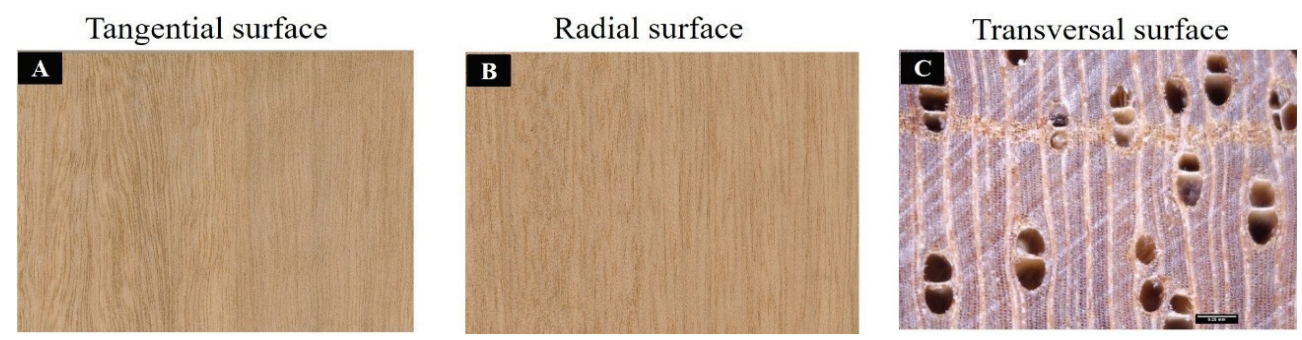

Fig. 6. Macroscopic features of Pisang Merah (H. hellwigii). 

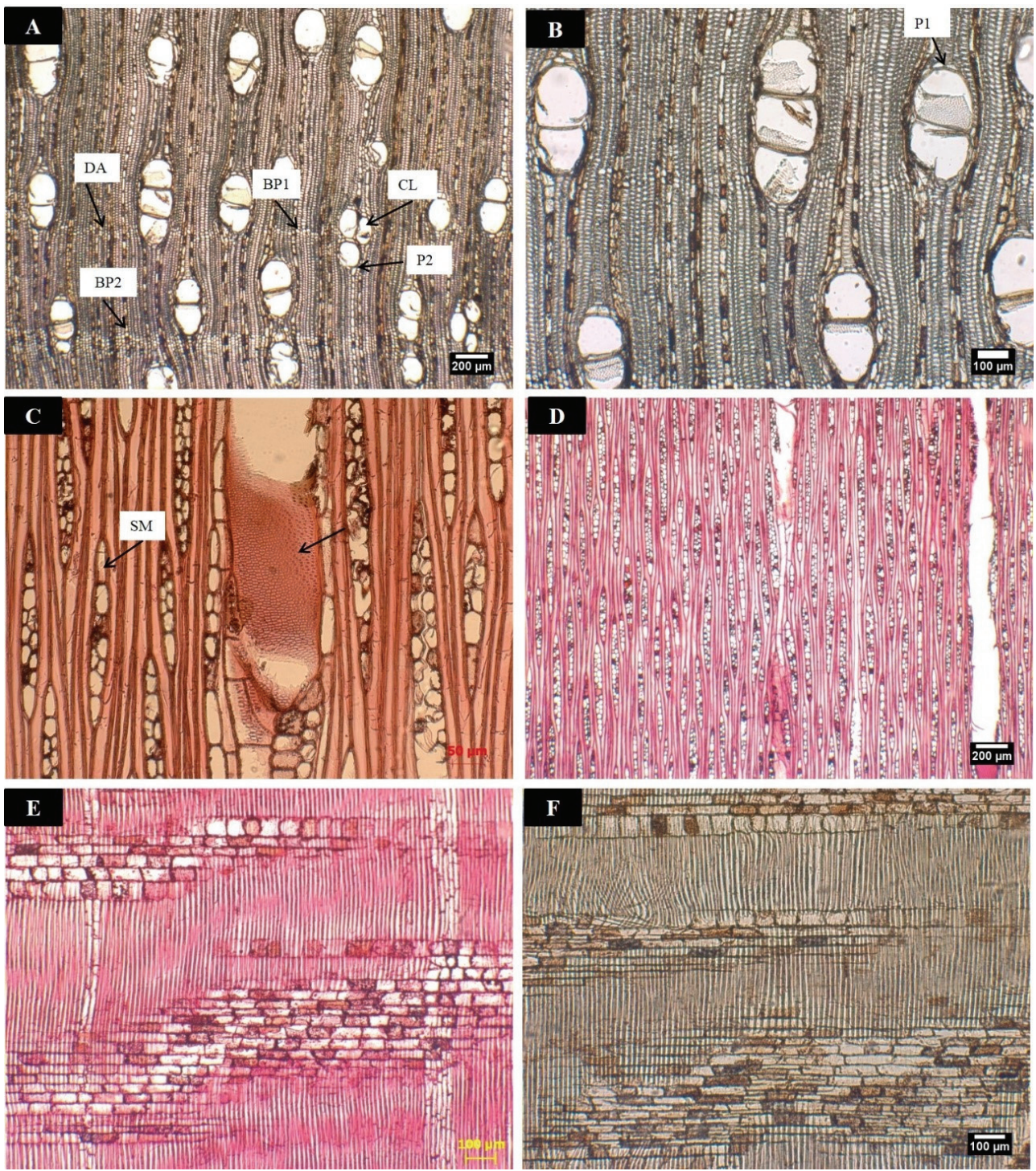

$\mathrm{BP} 1$ = narrow bands parenchyma

$\mathrm{P} 1$ = scanty parenchyma

$\mathrm{BP} 2$ = wide bands parenchyma

$\mathrm{P} 2$ = sheath narrow parenchyma

$\mathrm{CL}=$ clustered vessels

$\mathrm{SM}=$ oil and/or mucilage cells

$\mathrm{DA}=$ discontinuous tangential line parenchyma

Fig. 7. Microscopic features of Pisang Merah ( $H$. hellwigii).

found on the fiber type (septate), axial parenchyma type, without crystal, and the occurrence of oil cell. Un-similarities are found in vessel distribution (clustering is observed in our study), fiber length (ours is shorter), and the existence of silica (was not observed by them). Compared to Abdurrohim et al. (2004), the similarity was found in vessel distribution, vessel frequency, type of axial parenchyma, cell wall thickness, 
without crystal, and also tyloses. The unsimilarity was found in vessel diameter (our vessel is bigger), fiber length (ours is longer), ray width (theirs is wider), ray height (theirs is taller), ray frequency (ours is greater), and the occurrence of oil cell and silica (were not observed in their study).

\subsubsection{Terap ( $A$. odoratissimus)}

The result showed that heartwood is brown to reddish-brown and easy to differentiate from the sapwood (Fig. 8A). Wood texture is medium and even, the wood grain is interlocked (Fig. 8B), while the growth of ring boundaries are indistinct (Fig. 8C). The wood surface is slightly luster and has a distinctive odor. The measurement showed that the heartwood portion is $46.29 \%$.

Results also showed, that wood is diffuse-porous and there is no distinct difference in pore size between earlywood and the latewood. Vessels are mostly solitary but radial multiples of 2-4 cells are sometimes present (Fig. 9A). Average lumen diameter is 156.22 (61.06261.78) $\mu \mathrm{m}$ and 4 (2-8) cells per $\mathrm{mm}^{2}$. The solitary vessel is rounded in transversal section. Perforation plate is simple, while inter-vessel pitting is alternate with a polygonal shape (Fig. 9B: arrows). Gum, tyloses, and other deposits are present in the heartwood vessels (Fig. 9C: arrows).

Fibers are septate and non-septate (Fig. 9D: arrows), average length of 1709.66 (1199-2452.5) $\mu \mathrm{m}$, very thin-walled $(3.55 \mu \mathrm{m})$, and with simple to minutely bordered pits.

Axial parenchyma is wide and long (Fig. 9A\&E), mostly more than three cells in width and eight cells per strand. Apotracheal axial parenchyma is diffuse, while paratracheal axial parenchyma is aliform (Fig. 9A: P1), and confluent (Fig. 9A: P2).

Rays exclusively uniseriate (Fig. 9F), sometimes 1 to 3 cells width, the average height of 423 (210-854.56) $\mu \mathrm{m}$, and 5 (4-6) cells per mm. Body ray consists of procumbent cells with one row of square marginal cells. Silica bodies present in ray cells (Fig. 9G).

These findings have similarity and un-similarity with the previous study (Abdurrohim et al., 2004; Ogata et al., 2008). Compared to Ogata et al. (2008), the similarity was found in fiber length and fiber wall thickness; while the un-similarities are found in pore frequency (our findings is greater), type of axial parenchyma (vasicentric was not observed in our study), and type of fiber (septate fibers were not found by them). Compared to Abdurrohim et al. (2004), the similarity was found in vessel distribution, vessel frequency, type of axial parenchyma, cell wall thickness, and the presence of septate fibers; while the unsimilarity was found in vessel diameter (ours is smaller), fiber length (ours is longer), type of ray parenchyma (uniseriate in our sample, multi seriates in them), existence of crystal (was not observed in ours), and existence of silica (was observed in our study but was not observed by them).
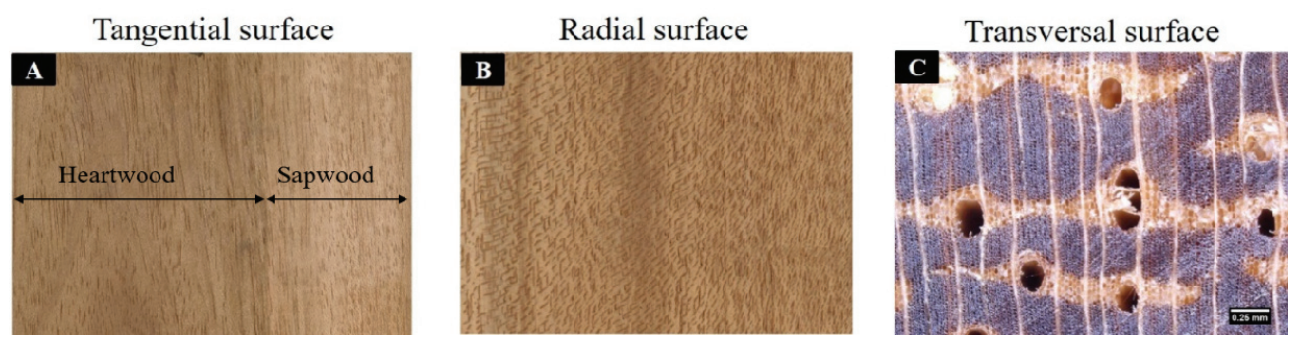

Fig. 8. Macroscopic features of Terap (A. odoratissimus). 
Anatomical Structures and Fiber Quality of Four Lesser-Used Wood Species Grown in Indonesia
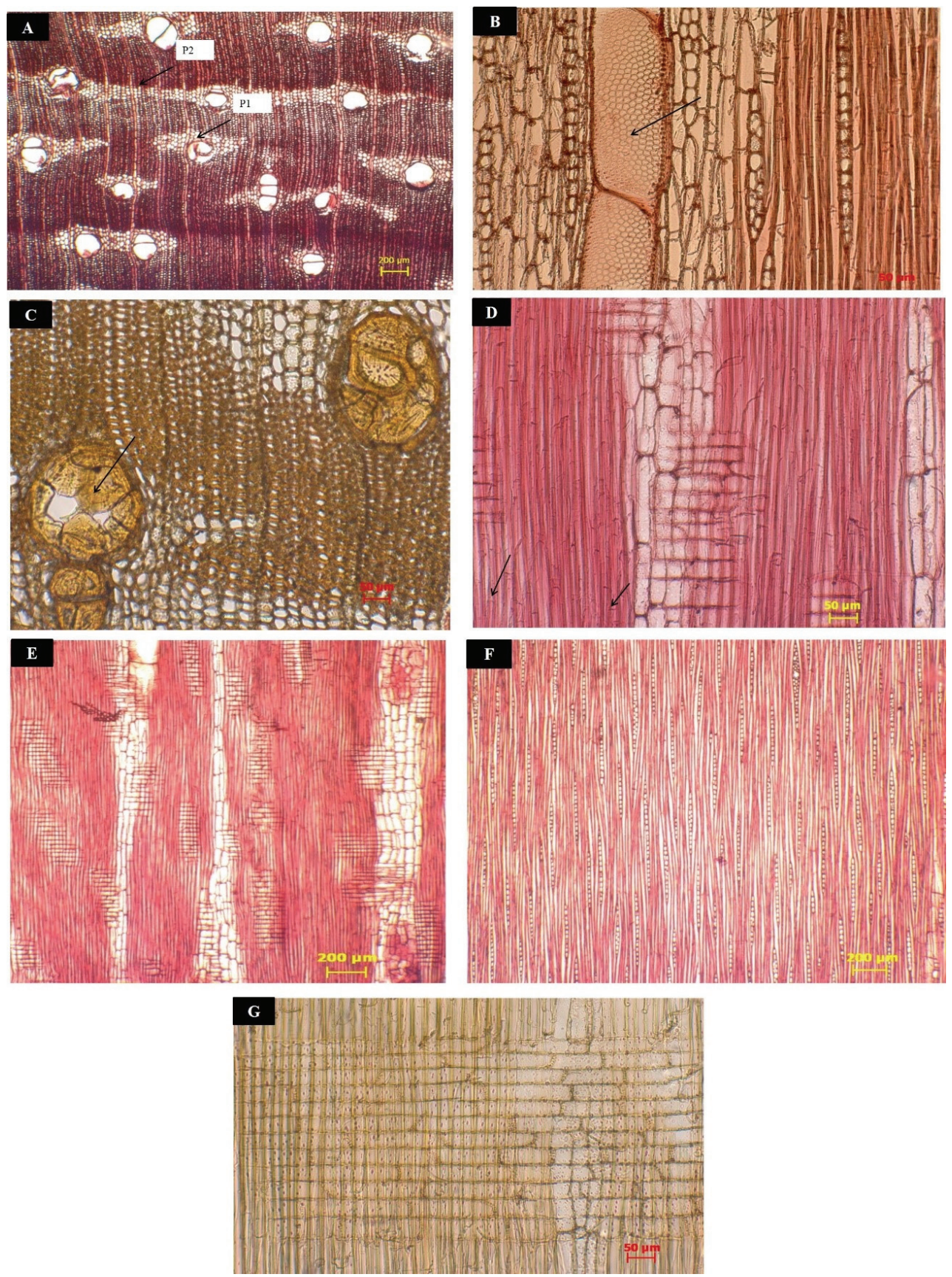

P1 = aliform parenchyma

$\mathrm{P} 2$ = confluent parenchyma

Fig. 9. Microscopic features of Terap (A. odoratissimus). 
Table 3. Fiber quality of each species based on fiber length and its derived values

\begin{tabular}{ccccc}
\hline Criteria & O. sumatrana & D. moluccana & H. hellwigii & A. odoratissimus \\
\hline \hline Fiber length $(\mu \mathrm{m})$ & 1565.60 & 1599.39 & 1691.86 & 1709.67 \\
RR & 0.26 & 0.31 & 0.35 & 0.38 \\
FP & 53.07 & 52.04 & 61.11 & 64.93 \\
MR & 58.58 & 40.06 & 85.36 & 93.02 \\
FR & 0.80 & 0.77 & 0.75 & 0.76 \\
CR & 0.10 & 0.12 & 0.13 & 0.13 \\
Scoring & 300 & 300 & 275 & 275 \\
\hline Class & II & II & II \\
\hline
\end{tabular}

\subsection{Fiber quality}

The fiber length of the four lesser-used species studied and their derived values, are tabulated in Table 3. It was confirmed that wood fiber of all species was classified into Quality Class of II. It means that the resulting pulp and paper would have good quality, especially in tensile, folding, and tear strengths. According to Rahman and Siagian (1976), the fiber of Quality Class II is easily beaten, and fiber bonding is particularly strong.

Even though in general they were categorized in the same quality class, however, some variation in the strength of pulp and paper and fiber length among the species also exists. In each wood species, fiber length tended to increase from pith (1st segment) to the bark (3rd segment) (Fig. 10). The latter phenomenon is correlated with the presence of juvenile wood (Tsuchiya and Furukawa, 2009; Tanabe et al., 2016).

Variation in the strength of pulp and paper in this study is more correlated to the derived value of the fibers since fiber length of the four wood species is almost similar (1560 to $1700 \mu \mathrm{m}$ ). Table 3 shown that Benuang wood has the lowest Runkel Ratio (RR), Terap wood has the highest Felting Power (FP), while Duabanga wood has the lowest Muhlstep Ratio (MR). All fibers have a similar Coefficient of Rigidity (CR) and Flexibility Ratio (FR). CR has a positive correlation

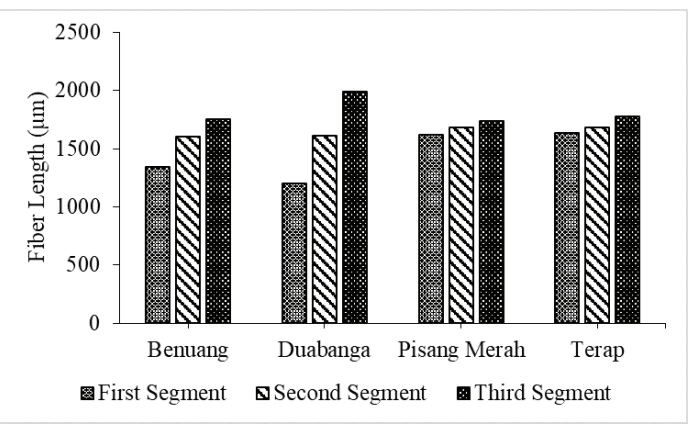

Fig. 10. Radial variation in fiber length of four lesser-used wood species.

with pulp yield and density, while FR has correlations: positive with tensile strength, folding resistance, and density; negative with the porosity of pulp and paper (Adi et al., 2014; Supartini and Dewi, 2010; Supartini et al., 2013).

According to Panshin and de Zeeuw (1980) and Adi et al. (2014), the lowest RR resulted in the highest tensile strength. Hence, pulp and paper made from Benuang wood will have the highest tensile strength. Felting power or slenderness ratio has a positive correlation with tear strength (Ververis et al., 2012). Hence, pulp and paper made from Terap wood will have the highest tear strength. A higher value of MR meant lower bonding and contact area between fibers. It means that pulp and paper with higher MR value made from Pisang Merah wood are not resistant to tear. 
Table 4. Quantitative characters of four lesser-used wood species

\begin{tabular}{|c|c|c|c|c|c|c|c|}
\hline \multirow[b]{2}{*}{ Anatomical characters } & \multicolumn{7}{|c|}{ Values } \\
\hline & $\begin{array}{c}O . \\
\text { sumatrana }\end{array}$ & $\begin{array}{c}D . \\
\text { moluccana }\end{array}$ & $\begin{array}{c}H . \\
\text { hellwigii }\end{array}$ & $\begin{array}{c}\text { A. } \\
\text { odoratissimus }\end{array}$ & $\begin{array}{c}\text { A. } \\
\text { mangium* }\end{array}$ & $\begin{array}{c}F . \\
\text { moluccana* }\end{array}$ & $\begin{array}{c}\text { Eucalypth } \\
\text { spp.* }\end{array}$ \\
\hline \multicolumn{8}{|l|}{ a) Vessel: } \\
\hline - Diameter $(\mu \mathrm{m})$ & $142-232$ & 197-384 & $72-220$ & $61-262$ & $150-280$ & $250-330$ & $230-310$ \\
\hline - Cell per mm² & 5 & 3 & 5 & 4 & $4-9$ & 2 & $6-12$ \\
\hline \multicolumn{8}{|l|}{ b) Rays: } \\
\hline - Ray height $(\mu \mathrm{m})$ & 738.10 & 210.81 & 449.89 & 423.83 & $230-450$ & $300-580$ & $430-680$ \\
\hline - Cell per mm & 5 & 5 & 9 & 5 & - & $5-6$ & - \\
\hline \multicolumn{8}{|l|}{ c) Fiber: } \\
\hline - Fiber length $(\mu \mathrm{m})$ & 1565.61 & 1599.39 & 1691.86 & 1709.66 & 1100 & 1300 & 1100 \\
\hline - Fiber diameter $(\mu \mathrm{m})$ & 29.38 & 35.55 & 27.46 & 26.72 & $15-30$ & 25 & $4-21$ \\
\hline - Lumen diameter $(\mu \mathrm{m})$ & 23.26 & 29.28 & 20.70 & 19.81 & $12-25$ & 21 & 11 \\
\hline - Fiber wall thickness $(\mu \mathrm{m})$ & 3.06 & 3.13 & 3.38 & 3.46 & $1.5-2.5$ & $1.5-2$ & $1-5$ \\
\hline \multicolumn{8}{|l|}{ d) Cell precentage: } \\
\hline - Vessel precentage (\%) & 12.75 & 19.33 & 12.77 & 5.40 & - & - & - \\
\hline
\end{tabular}

*Source: Donaldson (1984); Martawijaya et al. (2005); Ogata et al. (2008).

With the lowest in MR value, therefore, pulp and paper made by Duabanga wood will have the highest tear and tensile strength.

\subsection{Quantitative comparison to Mangium, Sengon, and Eucalyptus woods' characters}

Important quantitative of anatomical features and fiber dimensions of these four wood species are tabulated in Table 4. Data is then compared to the conventional woods namely Mangium (A. mangium), Sengon (F. moluccana), and Eucalyptus (Eucalyptus spp.) These are common raw material in pulp and paper manufacturing.

It showed that vessel diameter of Pisang Merah and Terap wood is smaller than the Mangium, Sengon, and Eucalyptus, while Benuang and Duabanga are equal to the three conventional pulpwood. For the vessel frequency, Duabanga wood has similar frequency to Sengon wood, while Benuang, Pisang Merah, and Terap similar to Mangium and Eucalyptus.

It also showed that Benuang wood has the tallest ray parenchyma compared the others, except for Eucalyptus. Ray parenchyma in Duabanga and Mangium woods is similar and categorized as the shortest.

In contrast to Mangium, Sengon, and Eucalyptus woods, the fiber length of the four wood species studied is longer. However, their cell wall is thicker. The latter phenomenon is a valid judgment to support the idea that pulp and paper from the fiber of Mangium, Sengon, and Eucalyptus woods are better than the four wood species' studied. According to Rachman and Siagian (1976), fibers of Mangium, Sengon, and Eucalyptus woods belong to Quality Class of I.

\section{CONCLUSION}

Fiber length and fiber quality class of Benuang, Duabanga, Pisang Merah, and Terap wood are similar, but their anatomical structures varied. The similarity 
in anatomical structures are found in growth ring, porosity, vessel outline, ray width, and deposits; while un-similarity are seen on vessel diameter size, vessel grouping, vessel frequency, the presence of tyloses, type of axial parenchyma, and ray height.

These lesser-used wood species are potential to be utilized as raw material for pulp and paper manufacturing. Their fibers belong to the Quality Class of II. Tensile, folding, and tear strengths of pulp and paper produced from all species studied are good. To promote their utilization, silviculture aspect of these four wood species has to be well understood and developed.

\section{ACKNOWLEDGMENT}

The authors would like to thank the Ministry of Research, Technology, and Higher Education of the Republic of Indonesia for funding this research under PMDSU grant.

\section{REFERENCES}

Abdurrohim, S., Mandang, Y.I., Sutisna, U. 2004. Indonesian Wooden Atlas Volume III. Forestry Engineering and Forest Product Processing R\&D Center-FORDA-Ministry of Forestry, Bogor, Indonesia.

Adi, D.S., Risanto, L., Damayanti, R., Rullyati, S., Dewi, L.M., Susanti, R., Dwianto, W., Hermiati, E., Watanabe, T. 2014. Exploration of unutilized fast growing wood species from secondary forest in Central Kalimantan: Study on the fiber characteristics and wood density. Procedia Environmental Sciences 20: 321-327.

Ali, A.C. 2011. Physical-mechanical properties and natural durability of lesser used wood species from Mozambique. Doctoral Thesis, Swedish University of Agricultural Sciences, Sweden.

Barnett, J.R., Jeronimidis, G. 2003. Wood Quality and
Its Biological Basis. Blackwell Publishing, Oxford, UK.

Donaldson, L.A. 1984. Wood anatomy of five exotic hardwoods grown in Western Samoa. New Zealand Journal of Forestry Science 14: 305-318.

Grünewald, H., Böhm, C., Quinkenstein, A., Grundmann, P., Eberts, J., von Wühlisch, G. 2009. Robinia pseudoacacia L.: A lesser known tree species for biomass production. Bioenergy Research 2: 123-133.

Hidayat, W., Kim, Y.K., Jeon, W.S., Lee, J.A., Kim, A.R., Park, S.H., Maail R.S., Kim, N.H. 2017. Qualitative and quantitative anatomical characteristics of four tropical wood species from Moluccas, Indonesia. Journal of the Korean Wood Science and Technology 45(4): 369-381.

Hidayati, F., Ishiguri, F., Marsoem S.N. 2017. Anatomical characteristics and air-dry density of young tree of Teak clones planted in Indonesia. Journal of the Korean Wood Science and Technology 45(4): 463-470.

Ishengoma, R.C., Gillah, P.R., Amartey, S.A., Kitojo, D.H. 2004. Physical, mechanical and natural decay resistance properties of lesser known and lesser utilized Diospyros mespiliformis, Tryachylobium verrucosum and Newtonia paucijuga timber species from Tanzania. Holz Roh Werkst 62: 387-389.

ITTO’s site. http://www.tropicaltimber.info/specie/be nuang-octomeles-sumatrana/ [Accessed 14 March 2019].

ITTO’s site. http://www.tropicaltimber.info/specie/dua banga-duabanga-moluccana/ [Accessed 14 March 2019].

ITTO’s site. http://www.tropicaltimber.info/specie/terap -artocarpus-scortechinii/ [Accessed 14 March 2019].

ITTO’s site. http://www.tropicaltimber.info/specie/pen arahan-horsfieldia-irya/ [Accessed 14 March 2019]. Junior, E.U., Terziev, N., Daniel, G. 2009. Wood anatomy of three lesser known species from Mozambique. IAWA Journal 30: 277-291. 
Anatomical Structures and Fiber Quality of Four Lesser-Used Wood Species Grown in Indonesia

Krisdianto, Barly, Abdurrohim, S., Mandang, Y.I. 2013 Indonesian Wooden Atlas Volume IV. Forestry Engineering and Forest Product Processing R\&D Center-FORDA-Ministry of Forestry, Bogor, Indonesia.

Mandang, Y.I. 2013. Xylarium Bogoriense and Its Role in Anatomical Research and Introduction of Various Wood Species in Indonesia. Forestry Engineering and Forest Product Processing R\&D Center-FORDAMinistry of Forestry, Bogor, Indonesia.

Martawijaya, A., Kartasujana, I., Kadir, K., Prawira, S.A. 2005 Indonesian Wooden Atlas Volume III. Forestry Engineering and Forest Product Processing R\&D Center-FORDA-Ministry of Forestry, Bogor, Indonesia.

Ogata, K., Fujii, T., Abe, H., Baas, P. 2008. Identification of the Timbers of Southeast Asia and the Western Pacific. Kaiseisha Press, Shiga-ken, Japan.

Ogunwusi, A. 2012. Characterization of wood cellular structures of five lesser used wood species growing in Nigeria. Journal of Natural Sciences Research 2(7): 128-134.

Olson, S.M. 2003. The wood properties of New Zealand silver beech (Nothofagus menziesii), a lesser-known hardwood species. Forest Products Journal 53(5): 80-86.

Panshin, A.J., de Zeeuw, C. 1980. Textbook of Wood Technology: Structure, Identification, Properties, and Uses of the Commercial Woods of the United States and Canada. McGraw-Hill Book Co., New York, USA.

Park, S., Jang, J., Wistara N.J., Hidayat, W., Lee, M., Febrianto, F. 2018. Anatomical and physical properties of Indonesian bamboos carbonized at different temperatures. Journal of the Korean Wood Science and Technology 46(6): 656-669.

Park, S., Kim, J., Kim, J., Yang, S., Kwon, O., Yeo, H., Cho, K., Choi, I. 2017. Possibility of wood classification in Korean softwood species using near-infrared spectroscopy based on their chemical compositions. Journal of the Korean Wood Science and Technology 45(2): 202-212.

Poku, K., Wu, Q., Vlosky, R. 2001. Wood properties and their variations within the tree stem of lesser-used species of tropical hardwood from Ghana. Wood and Fiber Science 33(2): 284-291.

Purusatama, B.D., Kim, Y., Jeon, W.S., Lee, J., Kim, A., Kim, N. 2018. Qualitative anatomical characteristics of compression wood, lateral wood, and opposite wood in a stem of Ginkgo biloba L. Journal of the Korean Wood Science and Technology 46(2): 125-131.

Rachman, A.N., Siagian, R.M. 1976. Fiber Dimension of Indonesian Wood Species Part III. LPHH Report No. 75. Forestry Engineering and Forest Product Processing R\&D Center-FORDA-Ministry of Forestry, Bogor, Indonesia.

Rulliaty, S. 1994. Wood quality indicators as estimator of juvenile wood in Mahogany (Swietenia macrophylla King) from forest plantation in Sukabumi, West Java, Indonesia. Thesis, University of the Philippines Los Baños, The Philippines.

Shupe, T.F., Aguilar, F.X., Vlosky R.P. 2005. Wood properties of selected lesser-used Honduran wood species. Journal of Tropical Forest Science 17(3): 438-446.

Soerianegara, I., Lemmens, R.H.M.J. (Eds.). 1993. Plant Resources of South-East Asia. No. 5 (1). Timber Trees: Minor Commercial Timbers. Pudoc Scientific Publishers, Wageningen, The Netherlands.

Statistics Bureau of Indonesia (BPS). 2014. Statistics of Forestry Production 2012. Statistics Indonesia, Jakarta, Indonesia.

Statistics Bureau of Indonesia (BPS). 2014. Statistics of Forestry Production 2013. Statistics Indonesia, Jakarta, Indonesia.

Statistics Bureau of Indonesia (BPS). 2015. Statistics of Forestry Production 2014. Statistics Indonesia, 
Jakarta, Indonesia.

Statistics Bureau of Indonesia (BPS). 2016. Statistics of Forestry Production 2015. Statistics Indonesia, Jakarta, Indonesia.

Statistics Bureau of Indonesia (BPS). 2017. Statistics of Forestry Production 2016. Statistics Indonesia, Jakarta, Indonesia.

Supartini, Dewi, L.M. 2010. Anatomical structure and fiber quality of Parashorea malaanonan. Jurnal Ilmu dan Teknologi Kayu Tropis 8: 169-176.

Supartini, Dewi, L.M., Kholik, A., Muslich, M. 2013. Anatomical structure and fiber quality of Shorea hopeifolia (Heim) Symington from East Kalimantan. Jurnal Ilmu dan Teknologi Kayu Tropis 11: 29-37.

Susila, I.W.Y. 2010. Annual increment of Duabanga (Duabanga moluccana) from Rarung. Jurnal Penelitian Hutan dan Konservasi Alam 7: 47-58.

Tanabe, J., Ishiguri, F., Nakayama, M., Ohshima, J., Iizuka, K., Yokota, S. 2016. Properties of juvenile and mature wood and their effects on the bending properties of lumber in Pinus taeda growing in
Tochigi, Japan. Forest Products Journal 66: 428-432.

Ververis, C., Georghiou, K., Christodoulakis, N., Santas, P., Santas, R. 2004. Fiber dimensions, lignin and cellulose content of various plant materials and their suitability for paper production. Industrial Crops and Products 19: 245-254.

Wahyudi, I. 2013. Relationship of Anatomical Structure, Wood Properties, Proper Utilization, and Wood Processing. Forestry Engineering and Forest Product Processing R\&D Center-FORDA-Ministry of Forestry, Bogor, Indonesia.

Wheeler, E.A., Baas, P., Gasson, P.C. 1989. IAWA list of microscopic features for hardwood identification. IAWA Bulletin 10: 219-332.

Yang, S., Park Y., Chung, H., Kim, H., Park, S., Choi, I., Kwon, O., Cho, K., Yeo, H. 2017. Partial least squares analysis on near-infrared absorbance spectra by air-dried specific gravity of major domestic softwood species. Journal of the Korean Wood Science and Technology 45(4): 399-408. 